\title{
A COMBINED PHYSICAL/MICROBIAL PROCESS FOR COAL BENEFICIATION
}

\section{$E 66-m-93358$}

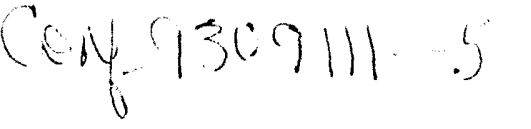

K. S. Noah, A. W. Glenn, C. J. Stevens, N. B. McAtee

M. E. McIlwain, and G. F. Andrews

Earth, Environmental, and Life Science

Idaho National Engineering Laboratory

P. 0. Box 1625, Idaho Fal1s, Idaho 83415-2203, USA

ABSTRACT

A combined physical/microbial process for the removal of pyritic sulfur from coal was demonstrated in a $200 \mathrm{~L}$ aerated trough slurry reactor. The reactor was divided into six sections, each of which acted as both a physical separator and a bioreactor. Settled solids from sections 2 through 6 were recycled to section 1 which acted as a rougher. The objective was physical removal of the larger pyritic inclusions, which would take many days to biodegrade, and biodegradation of the micropyrite, which is difficult to remove physically. The process was operated continuousiy for 8 months, treating two Illinois \#6 coals (4 months each). Reduction of $90 \%$ in.pyritic sulfur with $90 \%$ energy recovery and $35 \%$ ash removal was obtained for a low pyrite Monterey coal at a 5 day coal retention time and $20 \%(w / w)$ slurry concentration. Increased coal loading reduced performance apparently due to losses of sulfur oxidizing bacteria. A low pyrite Consol coal gave $63-77 \%$ pyrite reduction with $23-30 \%$ ash removal and $77-90 \%$ heating value recovery. Product coal pyritic sulfur analysis indicated no differences between treatments of Consol coal. This suggests that the coal residence time could be further reduced and the slurry concentration increased in future work.

\section{INTRODUCTION}

The overall objective of coal beneficiation is to produce a product low in sulfur and ash at the lowest possible cost and with minimum wastage of heating value. DOE's Coal Preparation Program has set a target of $90 \%$ removal of pyritic sulfur, but found this can only be achieved for most coals by physical processes (i.e., floatation, agglomeration) if the coal is ground to around $10 \mu \mathrm{m}$ [1]. The costs are high and must be charged to the coal cleaning step since grinding smaller than a boiler grind is not a normal cost associated with coal burning. Furthermore, such fine grinding greatly complicates the downstream processes of coal separation and drying.

The fine grinding requirement arises from the fact that pyrite exists as discrete inclusions with a wide range of sizes. The bulk of the pyrite in most coals occurs in few, relatively large inclusions, but there are millions of small inclusions (micropyrite). Coals in which these 


\section{DISCLAIMER}

This report was prepared as an account of work sponsored by an agency of the United States Government. Neither the United States Government nor any agency thereof, nor any of their employees, makes any warranty, express or implied, or assumes any legal liability or responsibility for the accuracy, completeness, or usefulness of any information, apparatus, product, or process disclosed, or represents that its use would not infringe privately owned rights. Reference herein to any specific commercial product, process, or service by trade name, trademark, manufacturer, or otherwise does not necessarily constitute or imply its endorsement, recommendation, or favoring by the United States Government or any agency thereof. The views and opinions of authors expressed herein do not necessarily state or reflect those of the United States Government or any agency thereof. 
contribute a significant fraction of the pyrite mass are difficult to clean physically with an acceptable loss of heating value, because the coal must be ground very fine in order to liberate the inclusions. The microbial process has several advantages for dealing with these small inclusions. First it does not require liberation, only exposure of the inclusion to bacterial attack at the coal particle surface so less grinding is needed. Second, the bacterial process dissolves the pyritic inclusions rather than separating them, so there is no loss of heating value in a reject stream. ". Third, the main drawback of the microbial process, it's low rate, disappears if it is focused on the micropyrite. If it takes bacteria 10 days to dissolve a $100 \mu \mathrm{m}$ inclusion, they will dissolve a $10 \mu \mathrm{m}$ inclusion in one day. A more quantitative version of this argument is given by Andrews et al $[3,4]$.

The work reported here demonstrated a combined depyritization process in which the large inclusions are removed physically -. (with some help from bacterial degradation) while the micropyrite is removed microbially (with some help from physical effects). The objective was to achieve the coal Preparation Program's objectives of $90 \%$ pyrite removal and $90 \%$ heating value recovery with hard-to-clean Illinois $\# 6$ coals ground to a normal boiler grind of approximately $100 \mu \mathrm{m}$.

\section{PROCESS FLOWSHEET}

The plexiglass aerated trough bioreacton was 8 feet long by 10 inches wide with a $v$-shaped base having a $30^{\circ}$ half-angle and could hold up to $200 \mathrm{~L}$ of slurry (Fig.1). In contrast to previous studies in which it was used purely as a bioreactor [3], the reactor was divided into six equal sections by solid baffles, each having a $1 / 4$ inch hole to allow passage of the coal slurry. Each section had its own aeration system consisting of a rigid acrylic tube covered with perforated silicone tubing, airflow control, and flow meter. The aeration system provided oxygen and carbon dioxide to the cells as well as kept the coal in suspension. Each section also had a drain in the bottom to allow removal of the heavier mineral particles that separate from the coal. These settled solids from sections 2 through 6 were returned to section 1 , which acted as a "rougher" section where the pyrite inclusions could be further degraded, liberating coal and producing biomass both of which flowed through the system again. The large mineral and pyrite particles that could not be degraded any further were removed from section 1 as solid waste. Feed coal was added dry to section 2 where it immediately formed a uniform slurry with the help of surfactants generated by the bacteria. The slurry left the reactor from section 6 and the product coal was separated on a dewatering screen. The liquid was held in a reservoir from where the bacteria, $\mathrm{Fe}^{+3}$, acid and biosurfactants were recycled to the first section. Ceil recycle is critical for maintaining a high concentration of bacteria in the process and the liquid recycle also helped to reduce the volume of wastewater generated. Wastewater was removed from the bottom of the reservoir to maximize the removal of fines and precipitates from the system. Recycle was quantified in terms of a hydraulic residence time,

$$
T_{\mathrm{H}}=\frac{1 \text { iquid volume in reactor }}{\text { liquid outflow from process }}
$$

When comparing $T_{H}$ to the reactor residence time, another main process variable 


$$
T=\frac{1 \text { iquid volume in reactor }}{\text { liquid inflow to reactor }}
$$

$T_{H} \gg T$ implies considerable liquid recycle while $T_{H}=T$ means, in the absence of evaporation and mist losses, no liquid recycle. Previous work [3] suggested that $T_{H}=2 T$ gave a good compromise between the benefits of recycle and the accumulation of inhibitory products around the recycle loop.

\section{PROCEDURES}

Details of the process start-up procedure have been described previously [3]. It involved growing large numbers of Thiobacillus ferrooxidans and Leptospirillum ferrooxidans on $\mathrm{Fe}^{+2}$. Adding smaller amounts of $\mathrm{T}$. thiooxidans, then adding coal and running the process in batch mode for 30 days before starting continuous operation. - This allows a well acclimated, consortium to develop from the initial bacterial population and species entering on the feed coal.

The process was started up with an Illinois \#6 coal provided by the Monterey Coal Company and ground to $80 \%-100$ mesh. - Four different steady-state conditions of reactor residence time, $T$ ( 3 to 5 days), process hydraulic residence time, $T_{H}$ ( 6 to 9 days), and coal slurry concentration, $W$ (strictly the slurry concentration in section 2) were studied. The last two $T_{H}$ values corresponded to zero wastewater production, the only liquid leaving the process being with the product coal and mist losses from the bioreactor. Since 3 to 4 residence times must be allowed to reach steady state conditions after changing any of these parameters, this took 148 days. The feed was then switched to another Illinois $\frac{\| 6}{\pi} 6 \mathrm{col}$ provided by Consolidation Coal Company and ground to $50 \%-100$ mesh. After a 47 day transition period under nominal conditions $W=20 \%$ and $T=5$ days ( 7 days for the first week) to el iminate all the Monterey coal from the reactor and to acclimate the bacteria to the new coal, the first steady state data was taken.

The following procedures were performed daily. Settled solids were drained from each section and dewatered on a vibrating screen. The liquid from section 2 through 6 was returned to the section whence it came, while the solids were weighed and added to section I. The solid waste from section 1 was analyzed for ash, and during certain steadystate periods, pyritic sulfur, while the liquid was distributed through sections 2 through 6 to make up their volume. The amount of solids drained from each section was computed from a process model based on a "separation factor" concept. The solid waste corresponded to 4 to $5 \%$ of the feed coal. The feed reservoir was weighed, and refilled if necessary with dechlorinated tap water, $\left(\mathrm{NH}_{4}\right)_{2} \mathrm{SO}_{4}$ (a bacterial nutrient) and $\mathrm{H}_{2} \mathrm{SO}_{4}$ to maintain the process $\mathrm{pH}$ around 2.0. The wastewater container was weighed, and a $4 \mathrm{ml}$ sample taken and acidified with $1 \mathrm{ml}$ of $6 \mathrm{~N} \mathrm{HCl}$ to dissolve any ferric hydroxysulfate precipitates. The sample was then filtered to remove fines and analyzed for sulfate by the barium chloride turbidimetric method and for total iron by atomic absorption spectroscopy. The wet coal cake that had accumulated on the dewatering screen was weighed and spread on a tray for drying to constant weight. A sample of wet coal cake (product coal) was taken and washed to remove sulfate and non-pyritic iron. The standard ASTM procedures for this step, boiling in $\mathrm{HCl}$, was found to be inadequate due to the high levels of ferric ion and sulfate in the interstitial water and precipitated on the coal. 
The steady-state performance when treating Monterey coal is summarized in Table 1. The ash in the product was $32-37 \%$ lower than in the feed. However, most of this reduction was due to dissolution of the basic minerals and pyrite. The solid waste contained less than twice the ash content of the feed, and this stream accounted for 10-18\% of the minerals in the feed coal. This is not good performance for a two-stage physical separation device,- and is-due to the fact that the aerated trough was originally designed as a pure bioreactor and its geometry has not been optimized for physical separation.

The heating value of the product coal was consistently $4-5 \%$ lower than the feed coal. This is believed to be due to oxidation and solubilization of some fraction of the coal organic matter by heterotrophic bacteria... Heating value -recovery was.-lower-with the $35 \%$ slurry because not all of the feed coal was accounted for in the product or solid waste stream. Some of this was due to accumulation of wet coal cake on the walls and roof of the reactor, and the remainder to loss of coal fines in the mist leaving the reactor with the airflow.

Pyrite in the solid waste accounted for $14-18 \%$ of the pyrite in the feed coal. Microbial oxidation calculated from pyritic throughput values (feed coal - product - drained) is approximately $70 \%$ for the $20 \%$ slurry and declined with increased slurry concentration and decreased residence time. This is thought to be due to the loss of sulfur-oxidizing bacteria, principally I. thiooxidans from the process. They are critical because they oxidize pyritic sulfur to sulfate. When the process is operating correctly the sulfur is oxidized as fast as the pyritic iron, and possible non-stoichiometric intermediates (e.g. elemental sulfur) will not reach detectable levels. However, the sulfur oxidizing bacteria must be attached to the solid surface, which means that they are less likely than the iron oxidizers to be in the liquid recycle and more likely to be lost from the process in the solid waste or the product coal. The rate of this loss will increase as the amount of coal being processed increases, and the result would be inadequate sulfur oxidizing capacity. Total sulfur analyses of the product coal were often higher than expected from the pyrite analyses (which actually measure pyritic iron) suggesting that elemental sulfur was being formed.

The steady-state performance when treating Consol coal is summarized in Table 2. The ash in the product was 23-30\% lower than the feed coal. Again, the solid waste contained less then twice the ash content of the feed.

For this coal, the heating value of the product matched the feed coal. However, the apparent heating value recovery was less than $80 \%$ for the $W=30 \%, T=5$ day, and $W=20 \%, T=7$ day conditions. However, this was probably an artifact due to the moisture content of the feed coal (7\%) which made it difficult to maintain a constant feed supply through the hopper.

Pyrite in the solid waste accounted for only $4-10 \%$ of the pyrite in the feed coal. This is lower than for the Monterey coal, but the Consol coal was already a fairly clean coal. Microbial oxidation was about the same as that of the Monterey coal, around $70 \%$, except for the first condition. This lower biological oxidation rate could be due to the bacteria adapting from the Monterey coal to the lower total sulfur Consol coal. The bacteria had over 30 days to adapt to Consol coal but could have 
continued adapting throughout the experiments.

Even though there was $63-78 \%$ pyrite reduction, the product pyritic sulfur valves from which those percentages were calculated were close enough in value to say that there was no difference in overall pyritic reduction between the three tireatments. This suggests that the residence time could be further reduced, the slurry concentration increased, and the same pyritic reduction could be achieved.

\section{CONCLUSIONS}

For the Monterey coal, the Coal Preparation objectives of $90 \%$ pyritic sulfur reduction with $90 \%$ recovery of heating value were met (based on total sulfur analysis) with $W=20 \%$ and $T=5$ days. Loss of heating value was due to the loss of coal in the solid waste and an apparent partial oxidation of the coal organic matter. - A.35\% reduction in ash was achieved. Approximately 15\% of the feed pyrite appeared in the solid waste, the remainder of the pyrite being microbially oxidized. Increased coal loading reduced sulfur removal due to loss of activity of the sulfur oxidizing bacteria attached to the product coal.

For the hard-to-clean consol coal, greater than $60 \%$ pyritic sulfur reduction, with greater than $20 \%$ ash reduction, with over $75 \%$ heating value recovery was achieved. Heating value recovery could be higher with use of better dry feed hoppers or the feed coal moisture content reduced. There was no difference in overall pyritic reduction between coal treatments, which suggests that coal loading could be increased in future work.

This work showed that simultaneous physical separation and bioleaching can give excellent results for coal depyritization. There is considerable scope for process improvements to improve the physical separation, retain sulfur oxidizing bacteria in the system, and reduce the residence times required.

\section{ACKNOWLEDGEMENTS}

This work was supported by the U.S. Department of Energy, Assistant Secretary for Fossil Energy under DOE Idaho Field Office Contract DEACO7-76ID01570. We would like to thank Monterey Coal Company and Consolidation Coal Company for supplying the coal and their "in-kind" support.

\section{REFERENCES}

1. L. L. Josephs and D. D. Ferris, Engineering developinent of advanced froth flotation - pyrite liberation study and round-robin flotation report, Proc. 6th Annual Coal Preparation Utilization and Environmental Control Contractors Conference, Pittsburgh, PA, August 1990, p. 298.

2. T. J. Feeley III, Coal surface control for advanced physical beneficiation, in: P. R. Dugan, D. Quigley, and Y. Attia (Eds), Processing and Utilization of High-Sulfur Coals IV, Elsevier, NY, 1991, pp. 195-204.

3. G. F. Andrews, P. R. Dugan, and C. J. Stevens, Combining physical and bacterial treatment for removing pyritic sulfur from coal, in: 
P. R. Dugan, D. Quigley, and Y. Attia (Eds), Processing and

Utilization of High-Sulfur coals IV, Elsevier, NY, 1991, pp. 515531 .

4. G. F. Andrews, C. J. Stevens, and J. Wey, The log-normal

distribution of pyritic inclusions in coal; consequences for depyritization, Proc. 3rd International Symposium on the

Bioprocessing of Coal, Clearwater, FL, May 1992, (Fuel; in press).

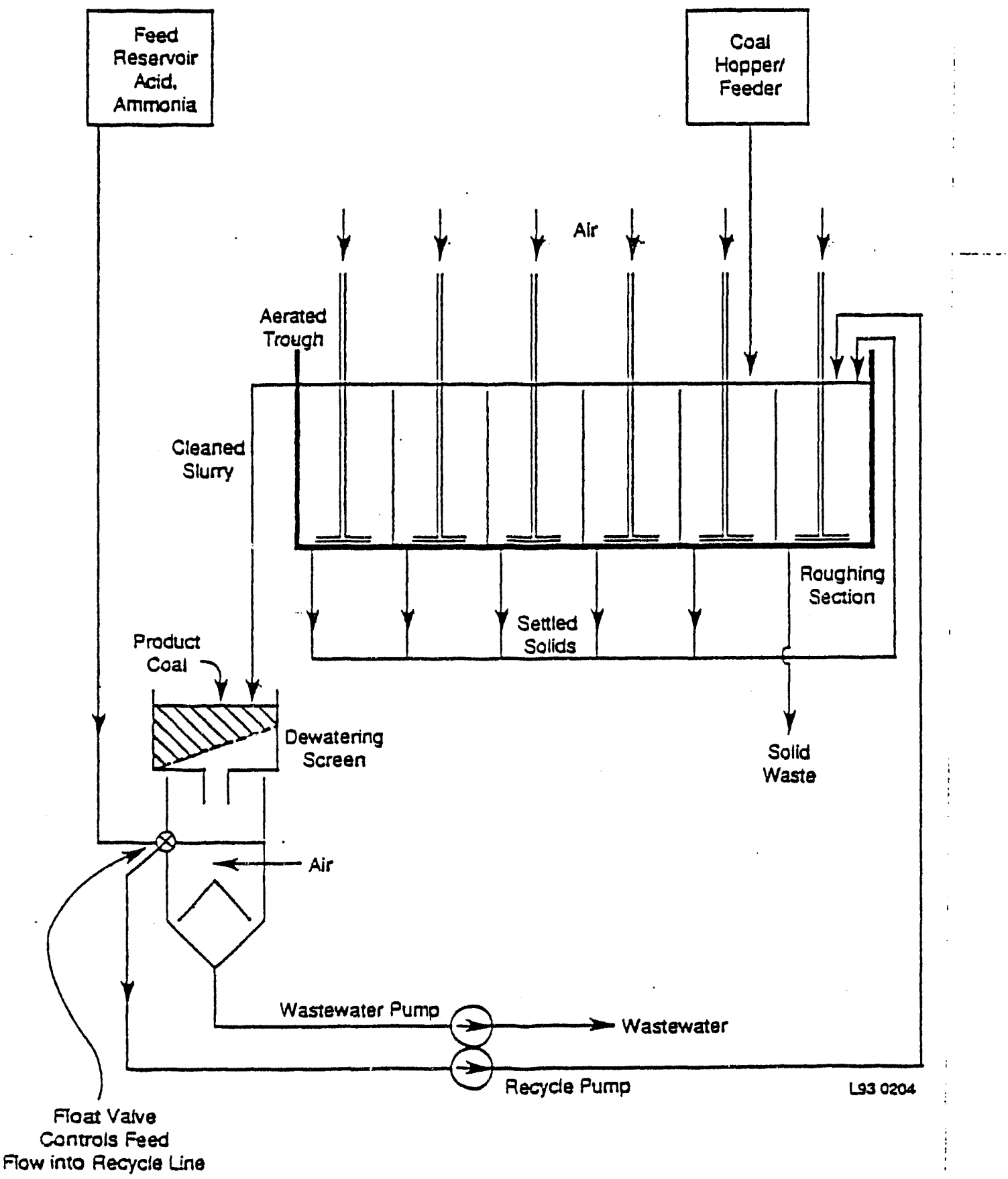

Figure 1. The physical/microbial process flowsheet. 
Table 1. Steady-State Process Performance Of Trough Reactor When Treating Monterey Coal

\begin{tabular}{|c|c|c|c|c|c|c|c|c|c|}
\hline & $\begin{array}{c}\text { \% Ash In } \\
\text { Product } \\
\text { Coal }\end{array}$ & $\begin{array}{l}\text { \% Ash In } \\
\text { Solid } \\
\text { Waste }\end{array}$ & $\begin{array}{l}\% \text { Ash } \\
\text { Reduction }\end{array}$ & $\begin{array}{c}\text { Product } \\
\text { lleating } \\
\text { Value } \\
\text { (BTU/lb) }\end{array}$ & $\begin{array}{c}\text { \% Heating } \\
\text { Value } \\
\text { Recovery }\end{array}$ & $\begin{array}{c}\text { Product } \\
\text { Total S } \\
\text { (\%) }\end{array}$ & $\begin{array}{l}\text { Product } \\
\text { Pyritic S } \\
(\%)\end{array}$ & $\begin{array}{c}\text { \% Physical } \\
\text { Removal }\end{array}$ & $\begin{array}{c}\% \\
\text { Microbial } \\
\text { Removal }\end{array}$ \\
\hline $\begin{array}{l}W=20 \% \\
T=5 \mathrm{~d} \\
T_{11}=5.8 \mathrm{~d}\end{array}$ & 6.0 & 10.0 & 37 & 11,912 & 89 & 3.11 & 0.21 & 16 & 63 \\
\hline $\begin{array}{l}W=20 \% \\
T=5 \mathrm{~d} \\
T_{11}=8.8 \mathrm{~d}\end{array}$ & 6.4 & 17.6 & 33 & 11,756 & 88 & 3.10 & 0.13 & 18 & 70 \\
\hline $\begin{array}{l}W=35 \% \\
T=5 d \\
T_{11}=9.3 d\end{array}$ & 6.0 & 17.3 & 37 & -- & -- & -- & 0.23 & 14 & 68 \\
\hline $\begin{array}{l}w=35 \% \\
T=3 \mathrm{~d} \\
T_{u}=6.0 \mathrm{~d}\end{array}$ & 6.4 & 17.8 & $3 ?$ & 11,962 & 80 & 3.89 & 0.38 & 16 & 53 \\
\hline Feed Coal & 9.55 & & & $12,700^{\circ}$ & & 4.04 & 1.02 & & \\
\hline
\end{tabular}

Table 2. Steady-State Process Performance of Trough Reactor When Treating Consol Coal

\begin{tabular}{|c|c|c|c|c|c|c|c|c|}
\hline & $\begin{array}{l}\text { \% Ash } \\
\text { In Product } \\
\text { Coal }\end{array}$ & $\begin{array}{l}\text { \% Ash } \\
\text { In Solid } \\
\text { Haste }\end{array}$ & $\begin{array}{c}\text { \% Ash } \\
\text { Reduction }\end{array}$ & $\begin{array}{l}\text { Product } \\
\text { lleating } \\
\text { Value } \\
\text { (BTU/Ib) }\end{array}$ & $\begin{array}{l}\text { \% Heating } \\
\text { Value } \\
\text { Recovery }\end{array}$ & $\begin{array}{l}\text { Product } \\
\text { Pyritic S } \\
\text { (\%) }\end{array}$ & $\begin{array}{c}\% \\
\text { Physical } \\
\text { Removal }\end{array}$ & $\begin{array}{c}\% \\
\text { Microbial } \\
\text { Removal }\end{array}$ \\
\hline $\begin{array}{c}W=20 \% \\
r=5 \mathrm{~d} \\
T_{11}=14.5 \mathrm{~d}\end{array}$ & 3.9 & 8.1 & 30 & 11,886 & 90 & 0.12 & 10 & 53 \\
\hline $\begin{aligned} w & =30 \% \\
T & =5 \mathrm{~d} \\
T_{11} & =9.1 \mathrm{~d}\end{aligned}$ & 4.2 & 8.8 & 23 & 12,840 & 78 & 0.091 & 4 & 74 \\
\hline $\begin{array}{c}W=20 \% \\
T=7 \mathrm{~d} \\
\tau_{u}=12.2 \mathrm{~d}\end{array}$ & 4.1 & 11.5 & 25 & 12,720 & 77 & 0.092 & 7 & 70 \\
\hline Feed Coal & 5.52 & & & 12,570 & & 0.315 & & \\
\hline
\end{tabular}



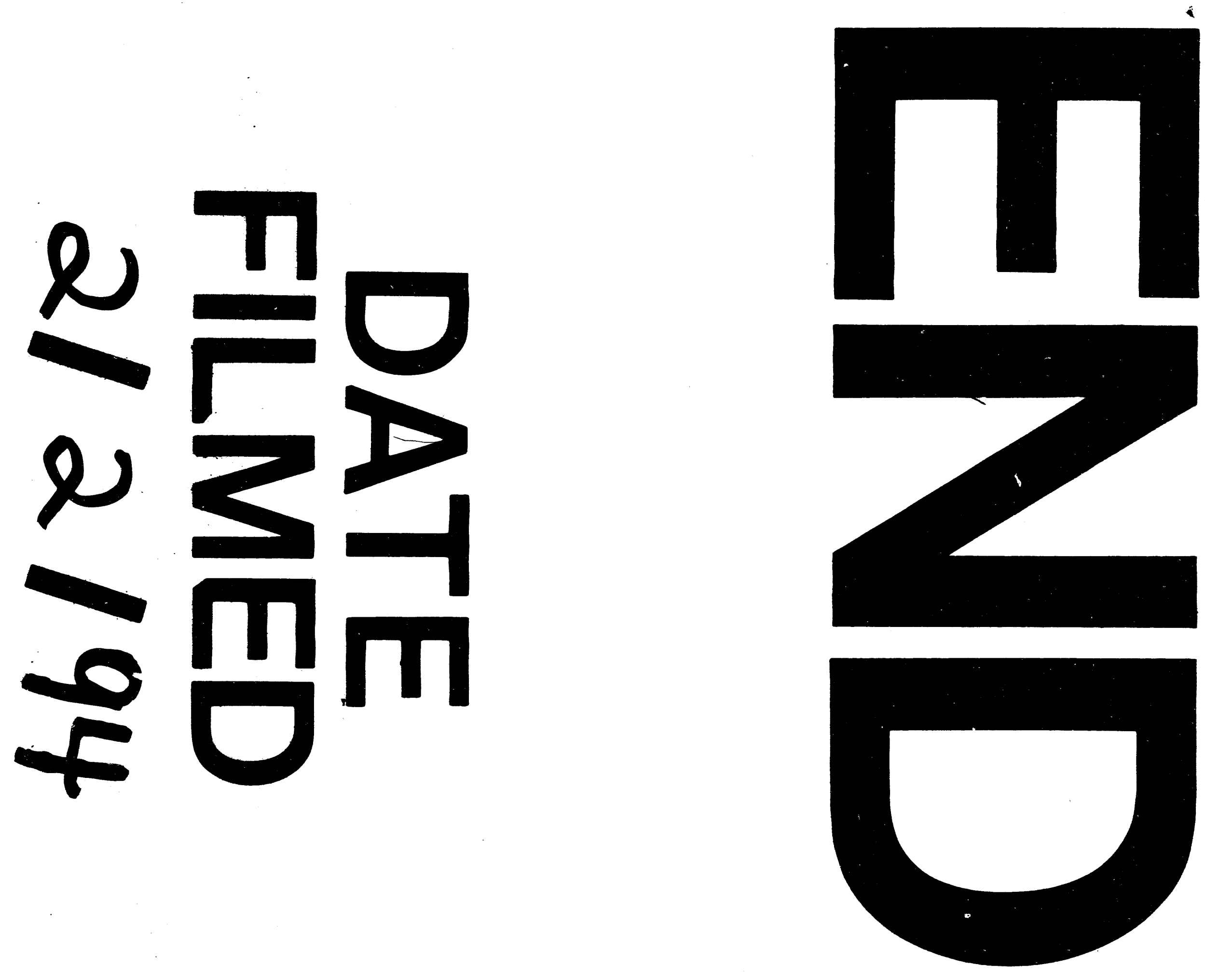
